\title{
ON THE STUDY OF SCYTHIAN MOBILITY BASED ON PALEOANTHROPOLOGICAL MATERIALS ${ }^{1}$
}

\author{
Maria V. Dobrovolskaya \\ Institute of Archaeology RAS, Moscow, Russian Federation \\ Semen A. Volodin \\ Institute of Archaeology RAS, Moscow, Russian Federation
}

\begin{abstract}
Introduction. The paper is about the study of the human skeletal remains isotopic composition from Middle Don burial mounds of the Scythian time to characterize the population mobility. Methods and materials. The materials from the monuments of Kolbino 1, Ternovoe 1, Gorki I, Devitsa V, Durovka are considered. Data on the isotopic composition of strontium enamel in teeth and bone tissue is used to estimate the mobility of the population. Information on the isotopic composition of bone carbon collagen and nitrogen is also used to reconstruct food models that reflect cultural traditions as well as environmental patterns. Analysis. Values of $87 / 86 \mathrm{Sr}$ of bone and tooth enamel are considered as markers of an individuals stay at different ages in a territory similar or different by geochemical parameters to regional Middle Don. Data on the isotopic composition of nitrogen and carbon in bone tissue from the burial mounds are considered with broad comparative data of the steppe Eurasian population of the Early Iron Age. Results. The authors discuss carbon delta values marking the use of $\mathrm{C} 4$ type photosynthesis plants. Millet is this cultural plant in Eurasian history of the Early Iron Age. This plant is widely spread in all steppe and nomadic cultures. The individual variability of carbon delta of Middle Don population is increased compared to all others. There are individuals who differ from the majority in lower carbon deltas corresponding to the $\mathrm{C} 3$ type of photosynthesis. This feature is proposed to consider as an evidence of contacts with the territories with the antique agriculture traditions.

Key words: Scythian time, Middle Don, kurgan graves, strontium isotopic composition, stable carbon and nitrogen isotopes, diet, mobility.

Citation. Dobrovolskaya M.V., Volodin S.A. On the Study of Scythian Mobility Based on Paleoanthropological Materials. Vestnik Volgogradskogo gosudarstvennogo universiteta. Seriya 4. Istoriya. Regionovedenie. Mezhdunarodnye otnosheniya [Science Journal of Volgograd State University. History. Area Studies. International Relations], 2020, vol. 25, no. 4, pp. 275-287. (in Russian). DOI: https://doi.org/10.15688/jvolsu4.2020.4.18
\end{abstract}

УДК 902.01

ББК 63.4
Дата поступления статьи: 14.06.2020

Дата принятия статьи: 15.07.2020

\section{ОБ ИЗУЧЕНИИ МОБИЛЬНОСТИ СКИФОВ ПО ПАЛЕОАНТРОПОЛОГИЧЕСКИМ МАТЕРИАЛАМ ${ }^{1}$}

\author{
Мария Всеволодовна Добровольская \\ Институт археологии РАН, г. Москва, Российская Федерация \\ Семен Алексеевич Володин \\ Институт археологии РАН, г. Москва, Российская Федерация
}

Аннотация. Введение. Статья посвящена обсуждению изотопного состава скелетных останков людей из курганных погребений скифского времени на Среднем Дону с целью охарактеризовать мобильность населения. В данном случае под мобильностью подразумевается подвижность, перемещения на другие территории на протяжении жизни человека. Meтоды и материалы. Рассматриваются материалы из памят- 


\section{БИОАРХЕОЛОГИЯ ДРЕВНИХ И СРЕДНЕВЕКОВЫХ ПОПУЛЯЦИЙ}

ников Колбино 1, Терновое 1, Горки I, Девица V, Дуровка. Для оценки мобильности населения используются данные об изотопном составе стронция эмали зубов и костной ткани. Также привлекаются сведения об изотопном составе углерода и азота коллагена костной ткани для реконструкции пищевых моделей, которые отражают и культурные традиции, и экологические особенности. Анализ. Величины $87 / 86 \mathrm{Sr}$ в кости и эмали зубов рассматриваются как маркеры пребывания индивида в различных возрастах на территории сходной или отличной по своим геохимическим параметрам от региональных среднедонских. Сведения об изотопном составе азота и углерода костной ткани из упомянутых курганных могильников анализируются на широком фоне сопоставительных данных степного евразийского населения раннего железного века. Результаты. Обсуждаются величины дельта-углерода, маркирующие употребление в пищу растений C4-типа фотосинтеза. В евразийской истории раннего железного века - это просо. Данное растение широко используется во всех степных и кочевых культурах. В группах из среднедонских курганных могильников индивидуальная изменчивость дельта-углерода повышена по сравнению со всеми другими. Встречаются индивиды, которые отличаются от большинства более низкими величинами дельта-углерода, соответствующими С3-типу фотосинтеза. Эту особенность предлагается рассматривать как свидетельство контактов с территориями, на которых распространены античные традиции земледелия. С.А. Володиным проводились полевые исследования, сбор и подготовка образцов для получения фоновых значений изменчивости изотопного состава стронция. М.В. Добровольской проведен сбор образцов палеоантропологических материалов, анализ полученных величин изотопного состава стронция, азота и углерода.

Ключевые слова: скифское время, Средний Дон, курганные погребения, изотопный состав стронция, стабильные изотопы углерода и азота, питание, мобильность.

Цитирование. Добровольская М. В., Володин С. А. Об изучении мобильности скифов по палеоантропологическим материалам // Вестник Волгоградского государственного университета. Серия 4, История. Регионоведение. Международные отношения. - 2020. - Т. 25, № 4. - С. 275-287. - DOI: https://doi.org/10.15688/ jvolsu4.2020.4.18

Введение. Круг актуальных тем современной скифологии очень велик, и далеко не последнее место занимает один из наиболее традиционных вопросов - о происхождении носителей традиций скифской культуры в широком понимании термина. Сегодня проблема обсуждается в формате широких краниологических сопоставлений [4; 13], сравнений пока не столь многочисленных палеогеномных данных [15]. Все исследователи указывают на сложность, многокомпонентность групп номадов. Примечательно, что процессы смешения в разных группах происходили с разной интенсивностью, что свидетельствует о различной степени демографической открытости палеопопуляций. Так, в частности, А.Г. Козинцев указывает на слабое сходство причерноморских скифов с местным населением и при этом подчеркивает их антропологическую неоднородность [4, с. 157].

Таким образом, миграционные процессы далеко не всегда приводили к смешению пришлых и местных групп. Если ранние скифы в Европейской части Евразии рассматриваются в контексте больших миграций, то в V в. до н. э. и особенно IV в. до н. э. скифские территории так стремительно не расширяются.
Их кочевой образ жизни выражается в иных формах мобильности. В связи с этим актуально создание представлений о подвижности образа жизни этих номадов в координатах индивидуальных онтогенезов. Очевидно, что задача эта новая, сложная и требует как подбора методов, так и накопления новых данных.

Методы и материалы. Наиболее распространенным в настоящее время методом, который фиксирует индивидуальную мобильность человека (или животного) на протяжении жизни, является анализ изотопного состава эмали зуба, минеральной или органической части кости. Суть подхода состоит в том, что компоненты тела формируются из веществ, так или иначе поступающих из окружающей среды, а разные типы скелетных тканей и эмаль обладают различной степенью консервативности. Они могут отражать как средовые обстоятельства периода роста (эмаль зуба), так и последних лет (кость) или даже последних месяцев и недель жизни (волосы и ногти). Под термином «средовые характеристики» мы можем понимать как специфику местных геохимических условий, так и особенности местной флоры и фауны, которые используются в пищу. 
Наибольшее распространение в настоящее время получил анализ соотношения изотопов стронция 87/86 Sr [16]. Так как это соотношение в первую очередь определяется фоном местных геологических пород, то может маркировать связь с ними.

Изучение изотопного состава углерода и азота коллагена кости используют для реконструкции основных пищевых источников. Дельты углерода $\delta^{13} \mathrm{C}$ и азота $\delta^{15} \mathrm{~N}$ определяются не только видом пищевого ресурса (растения С3- и С4-типов фотосинтеза, протеин сухопутных и морских животных и проч.), но и средовыми особенностями этих животных и растений. Пожалуй, особенно ярко это сказывается на домашних животных и сельскохозяйственных растениях $[17 ; 21]$. В связи с этим указанные данные могут быть использованы для реконструкции питания и индивидуальной мобильности человека.

Анализ. Фоновая изменчивость изотопного состава стронция и первые результаты изучения индивидуальной мобильности погребенных в курганах Среднего Дона. Могильники скифского времени, материалы которых послужили источниковой базой данного исследования, датируются второй половиной $\mathrm{V}-\mathrm{IV}$ в. до н. э. Эти памятники сооружались на высоких участках местности, образованных преимущественно крупными останцами отложений мелового периода (мел, мергели, пески) долины притоков Дона - Потудани и Девицы, - которые пролегают в пределах этих отложений. Долина Дона врезана глубже и углубляется в девонские отложения (известняки, песчаники).

Для оценки местной средовой изменчивости изотопного состава стронция были собраны образцы травянистой растительности с неглубокой корневой системой (злаки, бобовые) в разных участках рельефа от водораздельных до прирусловых. Также была взята раковина двустворчатого моллюска. Аналитические работы проведены Е.С. Богомоловым на базе Центра изотопных исследований Всероссийского научно-исследовательского геологического института им. А.П. Карпинского (Санкт-Петербург). Наименьшие величины определены для водораздельных участков, а максимальные - для растения из влажного прируслового участка. Растения и животные, жив- шие в условиях реки или близких к ней, характеризуются значениями стронциевого соотношения выше 0,7091 (максимальное - 0,7096). Растения с водораздельных участков характеризуются величинами $0,7084-0,7087$ (рис. 1).

Индивиды 1 и 2 из погребения 1 кургана 18 Колбино - это женщина старше 5060 лет и мужчина около 40 лет [9, с. 107-110]. Для мужчины был отобран образец эмали верхнего первого премоляра, для женщины эмаль нижнего клыка и костный фрагмент. Останки трех взрослых индивидов (женщина 20-29 лет и двое мужчин 40-49 лет) из курганов 5 и 6 могильника Девица $\mathrm{V}$ были потревожены в древности [2, с. 69-73]. В качестве образцов взяты участки компактной костной ткани крупных трубчатых костей конечностей молодой женщины и одного из мужчин.

Величины изотопного соотношения $87 / 86 \mathrm{Sr}$ компактно располагаются на верхней границе зоны местных значений, частично выходя за ее пределы (рис. 1). Также нами привлечены опубликованные ранее данные об изотопном составе стронция в эмали зубов и костей индивидов из погребений $2,4,7$, относящихся к катакомбной и срубной культурам эпохи бронзы, кургана 1 могильника Терновое 1 [1; 3]. Основные памятники этих культур располагаются в тех же самых ландшафтных зонах, что и скифские древности, следовательно, у нас есть основания сравнивать маркеры мобильности людей, разделенных столь значительным временным промежутком. Показатели индивидов из погребений эпохи бронзы также располагаются как на границе верхнего рубежа локальных значений, так и за ней (рис. 1).

Следует обратить внимание на то, что вариации изотопного состава образцов местной флоры и фауны больше, чем изменчивость изотопного состава кости людей. Это дает нам основание предполагать, что люди своей хозяйственной деятельностью были связаны с определенными микроландшафтными участками территории.

Отметим, что значения, определенные для эмали зубов, преимущественно находятся внутри границ локальной изменчивости. Так, 87/86 Sr индивидов из 18 кургана Колбинского могильника указывают, вероятно, на то, что детство этих людей проходило в среднедонском регионе. Все образцы костной ткани 


\section{БИОАРХЕОЛОГИЯ ДРЕВНИХ И СРЕДНЕВЕКОВЫХ ПОПУЛЯЦИЙ}

(и особенно образец костной ткани исследованной женщины из могильника Колбино 1) характеризуются величинами, выходящими за пределы известной нам границы локальной изменчивости.

В чем причина этой особенности? Мы можем рассматривать два варианта:

Вариант 1. Диагенетический фактор.

Вариант 2. Высокая мобильность на протяжении жизни, длительное пребывание на территориях, которые по геохимическому ландшафту несколько отличны от местных.

Анализируя первый из возможных вариантов, нужно заметить, что костная ткань более чувствительна ко внешнему воздействию со стороны грунта. Мы также видим, что в исследованных материалах показатели костных образцов выше, чем величины, полученные для эмали. Скелет молодой женщины из кургана 6 могильника Девица V представлен двумя образцами костной ткани. Один - компактная кость (фрагмент малой берцовой кости), другой - фрагмент губчатой кости позвонка. Результаты получились идентичными. Однако плотность компактной и губчатой кости различны и в случае загрязнения губчатая кость будет показывать значения, в большей степени обусловленные загрязнением. То обстоятельство, что скелетные показатели этой молодой женщины идентичны, означает, что кости не различаются по степени сохранности. Этот факт вызывает некоторые сомнения в верности первого варианта.

Остановимся на гипотезе, согласно которой люди, погребенные под курганами могильников Девица V и Колбино 1, имели очень высокую мобильность на протяжении всей жизни, но были погребены в местах, где они появились на свет. К сожалению, она пока имеет очень мало доказательств. Кроме того, необходимо заметить, что в таком случае мобильность индивидов из погребений эпохи бронзы оказывается выше даже для детского возраста (учитывая показатели образцов эмали зубов). Впрочем, данный вопрос выходит за рамки задач нашей статьи.

Рассмотрим возможные направления и территории, которые могли быть местом пребывания последних лет жизни погребенных. Для сравнения мы можем привести данные, полученные при анализе костных материалов из памятников, расположенных к северу от изучаемого микрорегиона (рис. 2). Это захоронения на Семилукском городище возле Воронежа и грунтовые захоронения в могильнике Ксизово-17 на Верхнем Дону [6; 7]. Очевиден большой разброс значений, тем не менее некоторые индивиды из грунтовых погребений Ксизово и даже местный скот идентичны по своим величинам стронциевого показателя с людьми, погребенными под курганами. В связи с этим вариант пребывания последних на протяжении жизни в более северных лесостепных районах не исключен. Следует, однако, обратить внимание на то, что общая тенденция в распределении величин стронциевого соотношения в образцах с относительно северных территорий проявляется в более резком увеличении $87 / 86 \mathrm{Sr}$ до 0,7105 и выше.

Изотопное соотношение стронция в пределах от 0,7095 до 0,7100 может быть встречено и на более южных территориях вплоть до Северного Причерноморья [14, с. 94]. Публикация данных о величинах стронциевого соотношения в образцах из скифских погребений Поднепровья с территории Украины позволяет убедиться, что в основном они укладываются в интервал от 0,709 до 0,710 [18, p. 171]. Таким образом, известные к настоящему времени величины стронциевого соотношения как в среде, так и в археологических образцах очерчивают широкую область, пребывание в которой могло бы сформировать те значения изотопного состава стронция, которые мы наблюдаем в исследованных нами образцах. Впрочем, для того чтобы считать эти области связанными с мобильностью среднедонских уроженцев, необходимо привлечение как большего числа образцов, так и других независимых источников.

В любом случае проведенные исследования позволяют видеть, что среди первых четырех индивидов, изученных нами, как минимум двое были местными уроженцами, а не мигрантами из отдаленных районов. Высокая индивидуальная мобильность могла проявляться в долговременном пребывании на территориях с определенными геохимическими условиями.

Влияние фактора импортной пищи мы пока не рассматриваем, так как ведущую роль 
в формировании изотопного состава стронция скелета играет питьевая вода. Возможно, в отдельных случаях пищевой импорт может оказывать свое влияние, однако это должна быть исключительная ситуация практически полного отказа от местных пищевых ресурсов.

Данные об изотопном составе азота и углерода коллагена костной ткани в оценке мобильности и традиций питания среднедонского скифского населения. Как известно, данные об изотопном составе азота и углерода широко применяются для реконструкции традиций питания. Привлечение широких сопоставительных данных с группами евразийского кочевого и скотоводческого населения раннего железного века для сопоставления с аналогичными характеристиками у среднедонского населения скифского времени мы считаем эффективным по двум причинам. Во-первых, это дает возможность оценить своеобразие пищевых моделей курганного среднедонского населения на фоне традиций питания различных степных культур. Вовторых, мы сможем оценить изменчивость изотопных параметров и провести их интерпретацию с целью дифференциальной диагностики причин формирования этой изменчивости. Напомним, что не только сам по себе состав нутриентов усредненного рациона (пищевая модель) определяет величины дельтаазота и углерода, но и те экологические обстоятельства, в которых происходит выращивание сельскохозяйственной продукции, используемой в пищу.

В качестве сопоставительных данных привлечены опубликованные индивидуальные значения дельта-азота и углерода у взрослых индивидов из коллективных погребений в срубах скифского времени могильника Аймырлыг в Туве [20]; могильников Хулунбиер и Улангаб в Китае [19]; могильника Хейгоулианг в Западном Синьцзяне [23]; некрополей тасмолинской культуры в Казахстане [10].

На рисунке 3 представлены опубликованные ранее данные по образцам коллагена костной ткани взрослых индивидов из пяти курганных могильников Среднего Подонья: Колбино 1, Терновое 1, Горки 1, Дуровка, Девица V $[11 ; 12]$. Здесь же привлечены немногочисленные данные по индивидам из грунтовых погребений Ксизово-17 и одному взрос- лому индивиду из Семилукского городища [8, с. 81]. Рассмотрим положение изотопных показателей среднедонских скифов на широком евразийском фоне. Хотя наши сопоставительные материалы очень разнообразны, но все они могут быть отнесены к степным евразийским скотоводческим традициям.

Ранние этапы существования культуры Туоба Ксианбей (Внутренняя Монголия) связаны с началом длительного взаимодействия степных кочевых культур с оседлым земледельческим населением Китая. Исследователи проанализировали многочисленный материал первой половины первого тысячелетия н. э. и выявили, что на ранних этапах этого взаимодействия кочевники сохраняют свои изначальные традиции питания и лишь постепенно приобщаются к пищевой культуре и хозяйству оседлых культур [19]. В качестве сопоставительного материала нами взяты данные раннего и среднего периодов (25-200 гг. н. э. и 120-386 гг. н. э. соответственно). Величины дельта-азота и углерода, полученные для наиболее ранних индивидов, близки к значениям, характерным для скифов из коллективных срубов Аймырлыга и отчасти к среднедонским показателям. Эти сведения представляют важный результат: постепенное культурное взаимодействие двух традиций хозяйствования сказывается в изменении питания и отражается в изотопных показателях.

Памятник Хейгоулианг, расположенный в Западном Синьцзяне, представляет погребения номадов высокого социального статуса ${ }^{2}$. Погребения датируются широко - первым тысячелетием до н. э. [23]. Индивидуальные значения группируются плотно, что свидетельствует о четких традициях питания.

Важны для нас и исследования группы индивидов из различных памятников тасмолинской культуры Казахстана VIII-V вв. до н. э. Носители традиций этой культуры не являются классическими номадами раннего железного века, однако скотоводство было сильно развито в комплексном хозяйстве этого населения.

Прежде всего отметим, что изменчивость величин дельта-углерода для среднедонских насельников очень высокая и, вероятно, не находит аналогов среди привлеченных сопоставительных данных (рис. 3). Наиболее 


\section{БИОАРХЕОЛОГИЯ ДРЕВНИХ И СРЕДНЕВЕКОВЫХ ПОПУЛЯЦИЙ}

компактной является группа из погребений Синьцзяна. Возможно, это объясняется высоким социальным статусом всех погребенных. Эти данные сопоставимы с одной из группировок внутри зоны индивидуальной изменчивости наших материалов. Люди тасмолинской культуры также имеют четкую локализацию изотопных показателей в области умеренных величин дельта-углерода и очень высоких значений дельта-азота. Последняя характеристика, предположительно, связана как с высокой аридностью климата, так и с возможными ограничениями в территории выпаса скота. От таких ограничений привнесение в почву органического азота, обогащенного тяжелым изотопом, резко повышается. Изотопные показатели «тасмолинцев», как правило, существенно отличаются от величин, определенных для курганного населения Среднего Дона.

В зоне низких значений дельта-азота находятся индивиды из грунтовых погребений верхнедонского Ксизово-17, что указывает на иную структуру их хозяйства и питания. Этот тезис подтверждается и явным смещением величин дельта-углерода в зону растений С4типа фотосинтеза (проса). Изотопные соотношения стронция в образцах из тувинских скифских погребений (Аймырлыг) частично перекрываются с величинами, полученными для памятников Среднего Дона. Но значительная их часть находится в зоне более высоких значений как дельта-азота, так и дельта-углерода. Это обстоятельство указывает на существенную долю блюд из проса в их рационе, а также, вероятно, на иные условия выпаса животных.

По активности использования проса люди из коллективных погребений Аймырлыг похожи на жителей Внутренней Монголии, особенно на ранних этапах существования пастухов культуры Туоба Синбэй (до начала аккультурации с китайскими земледельцами). Средний же этап этой культуры уже демонстрирует начало снижения величин дельтаазота и повышение дельта-углерода, что характеризует переход к модели питания с большим растительным компонентом и количеством проса.

Таким образом, мы можем выделить две группы, каждая из которых по-своему проявляет сходство с параметрами, определен- ными для среднедонского населения. Это группа людей из высокостатусных погребений Западного Синьцзяна и отчасти Аймырлыг (Тува). Особое внимание обращает на себя значительная индивидуальная изменчивость дельта-углерода в среднедонской объединенной выборке, которая не наблюдается ни в одной из представленных групп.

Напомним, что величина дельта-углерода зависит в первую очередь от начального уровня трофической пирамиды - от растений, которыми питаются люди и животные. Глядя на размах данных более чем в восемь промилле, можно заключить, что люди, погребенные в курганах Среднего Дона, были крайне неоднородны по пристрастию к просу.

Постепенное распространение культуры разведения и употребления проса с территории современного Китая по степному коридору кочевыми культурами эпох раннего металла и раннего железного века неоднократно обсуждалось в литературе [22]. В той или иной степени участие проса в питании просматривается у всех изученных групп (менее всего - у людей из Синьцзяна). Между тем среди погребенных в курганных могильниках Среднего Дона есть индивиды, которые полностью укладываются в модель питания на основании С3-типа растений. Они не готовили из проса, да и величины дельтаазота у них не высоки, что, возможно, связано с иными условиями содержания и выпаса домашних животных.

Как уже отмечалось выше, на примере диахронного исследования погребенных в могильниках Внутренней Монголии показано, что взаимодействие с другой культурой оказывает влияние на изменения исходной пищевой модели кочевника. Если мы с этой точки зрения посмотрим на значительные вариации дельта-углерода у людей из погребений на Среднем Дону, то возникает желание провести прямую аналогию. Возможно, мы имеем дело с длительным культурным контактом с обществами, в которых не было принято широкое употребление проса, а присутствовали другие растения С3-типа фотосинтеза, либо с отдельными представителями других традиций питания.

Прежде всего, следует ответить на вопpoc: насколько значимо это разделение на лю- 
дей, ориентированных на растительную пищу C3- и C4-типов фотосинтеза. Для этого был проведен кластерный анализ, который показал, что в первые два кластера всех значений среднедонского региона разделяют индивидов с относительно низкими величинами дельтауглерода и относительно высокими. Группировку индивидов со значениями дельта-углерода от $-17,5$ \%о до -13,5 \%о мы связываем с типично кочевнической пищевой моделью, в которой преобладают животные белки и стабильно присугствует просо. Группировка со значениями $\delta^{13} \mathrm{C}$ от $-21 \%$ до -18 \%о объединяет людей, растительная пища которых тяготеет к растениям С3-типа фотосинтеза.

Обратимся к археоботаническим исследованиям культурных слоев памятников Среднего и Нижнего Дона. Е.Ю. Лебедева отмечает два обстоятельства, характеризующие среднедонские поселения: чрезвычайная слабая насыщенность растительными остатками, лидирующее число зерен и других остатков проса [5, с. 124]. Разительно отличается от этой ситуации Елизаветовское городище в устье Дона, культурный слой которого насыщен фрагментами других культурных злаков, среди которых лидируют ячмень и пшеница. Возможно, что наличие двух кластеров внутри пространства индивидуальной изменчивости показателей изотопного состава углерода и азота связано с активными контактами с более южным населением, выращивающим ячмень и пшеницу.

Е.Ю. Лебедева отмечает: «Создается впечатление, что как только мы попадаем в зону более тесных контактов и даже непосредственного соседства скифского (или же меотского) населения с античными причерноморскими центрами, следы занятия земледелием на таких памятниках становятся гораздо более яркими и очевидными» [5, с. 126]. Мы, со своей стороны, отмечаем следы влияния иной традиции питания, которая отлича- ется от типичной степной кочевнической модели и ориентирует на причерноморские земледельческие районы. Означает ли это, что люди с низкими величинами дельта-углерода проводили долгое время на этих землях, или они придерживались этих пищевых традиций, оставаясь жителями отдаленных лесостепных областей? Для ответа на этот вопрос необходимы дальнейшие исследования.

Результаты. Изотопный состав углерода, азота и стронция скелетных останков людей из погребений под курганными насыпями в могильниках скифского времени на Среднем Дону был использован нами для реконструкции мобильности и векторов взаимодействия с окружающими территориями. Изотопный состав стронция позволяет предположить, что местные уроженцы могли проводить длительное время на других территориях, но были захоронены на «родовых» землях. Различия в традициях употребления проса, отраженные в показателях изотопного состава углерода, дают основание видеть в этом результат взаимодействия с античными культурными центрами.

\section{ПРИМЕЧАНИЯ}

${ }^{1}$ Работа выполнена при финансовой поддержке РФФИ в рамках исследовательского проекта № 18-09-00159 «Хозяйство и быт населения Среднего Дона в скифское время: по данным естественных наук и археологии».

This work was financially supported by the Russian Foundation for Basic Research within the framework of a research project no. 18-09-00159 "Economy and mode of life of the Middle Don population during the Scythian time: according to the data of the natural sciences and archaeology".

${ }^{2}$ В статье приведены данные как о погребенных в собственных могилах, так и принесенных в жертву. Мы обсуждаем в данном случае только данные о тех, для кого создавались эти погребения. 


\section{БИОАРХЕОЛОГИЯ ДРЕВНИХ И СРЕДНЕВЕКОВЫХ ПОПУЛЯЦИЙ \\ ПРИЛОЖЕНИЕ}

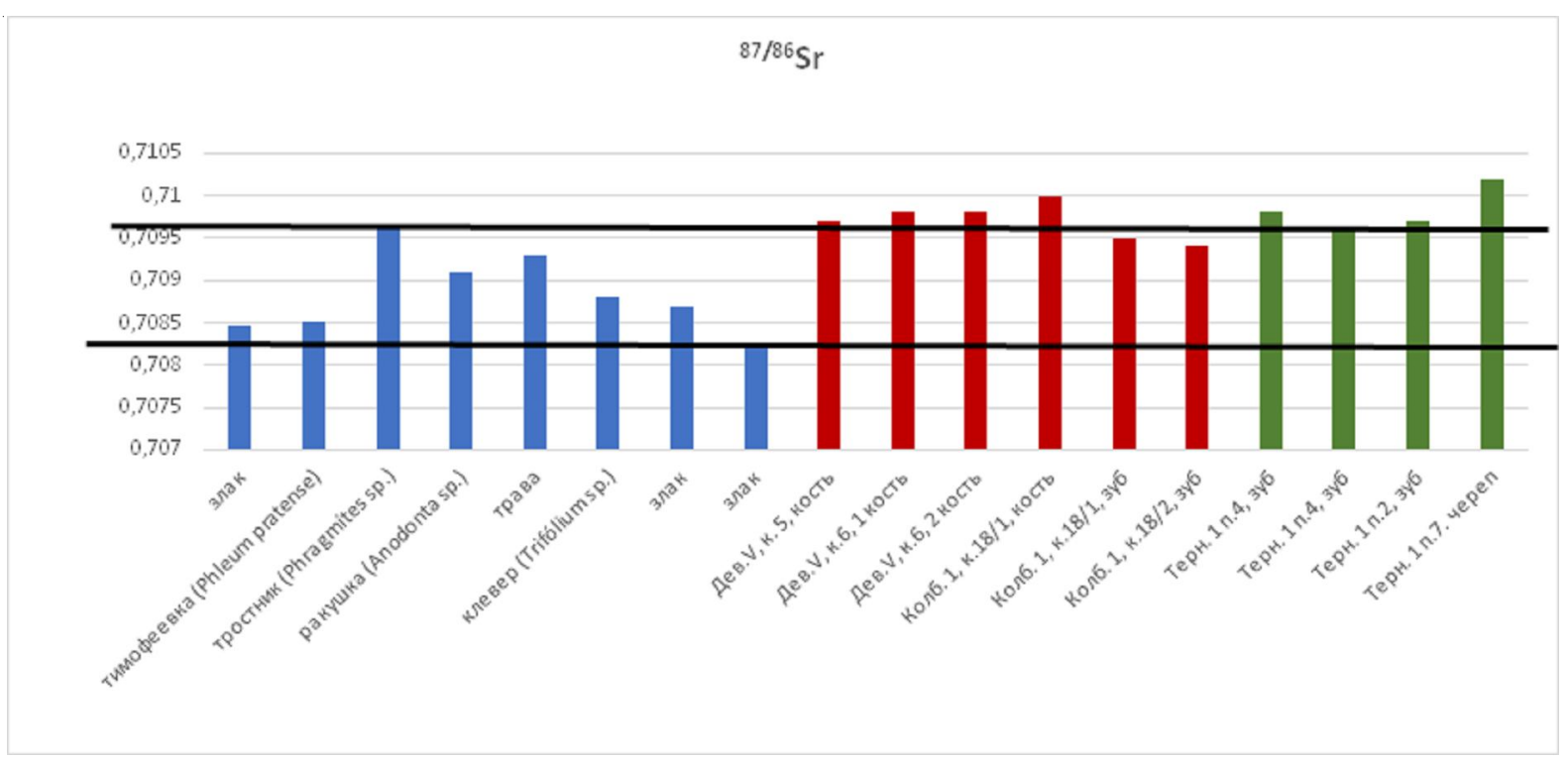

Рис. 1. Изотопный состав стронция в объектах среды и в скелетных останках людей из среднедонских курганов скифского времени (Коблино 1, Девица V) и эпохи бронзы (Терновое 1)

Fig. 1. Isotopic composition of strontium in environmental objects and in the skeletal remains of people from the Middle Don kurgans of the Scythian time (Koblino 1, Devitsa V) and the Bronze Age (Ternovoe 1)

Примечание. Черными горизонтальными линиями обозначены границы изменчивости местных значений. Note. Black horizontal lines mark the borders of the local variability.

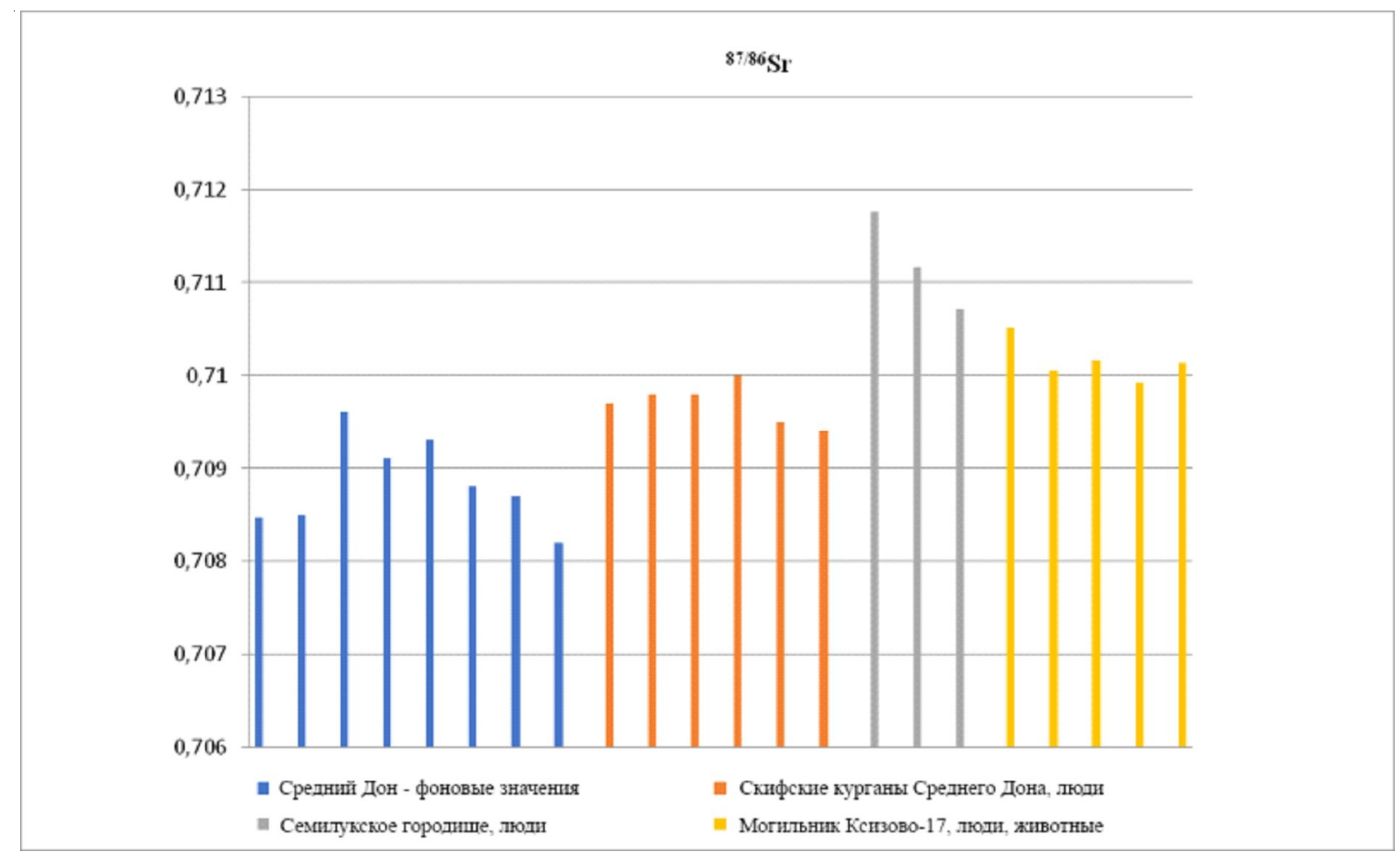

Рис. 2. Сопоставление величин изотопного соотношения стронция $87 / 86 \mathrm{Sr}$

Fig. 2. Comparison of the strontium isotope ratio $87 / 86 \mathrm{Sr}$ 
Об изучении мобильности скифов по палеоантропологическим материалам

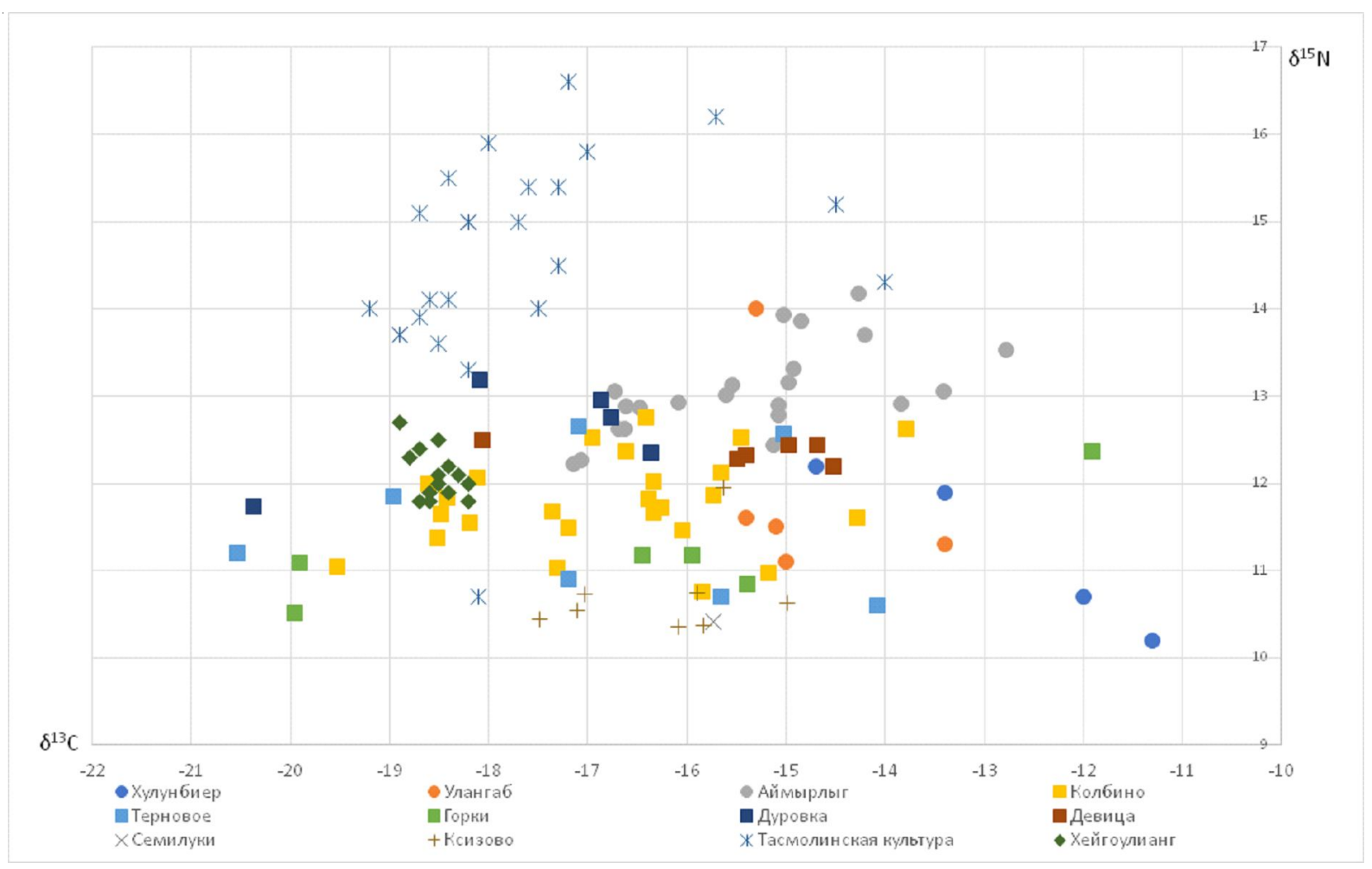

Рис. 3. Величины дельта азота и углерода в коллагене костной ткани людей из погребений на территории Евразийских степей в раннем железном веке

Fig 3. Values of the delta of nitrogen and carbon in the collagen of the bone tissue of people from burials in the Eurasian steppes in the Early Iron Age 


\section{СПИСОК ЛИТЕРАТУРЫ}

1. Гей, А. Н. Курган бронзового века в могильнике Терновое I / А. Н. Гей // Археология Среднего Дона в скифскую эпоху : труды Потуданской археологической экспедиции ИА РАН. - М. : ИА РАН, 2001. - С. 7-18.

2. Гуляев, В. И. Новые курганные могильники скифского времени на Среднем Дону: Горки I и Девица V / В. И. Гуляев, А. А. Шевченко. - М. : ИА РАН, 2017. - $156 \mathrm{c}$.

3. Добровольская, М. В. Изотопное исследование антропологических материалов из погребальных памятников эпохи бронзы на Среднем Дону / М. В. Добровольская, И. К. Решетова // Краткие сообщения Института археологии. 2016. - № 245-II. - C. 172-181.

4. Козинцев, А. Г. Скифы Северного Причерноморья: межгрупповые различия, внешние связи, происхождение / А. Г. Козинцев // Археология, этнография и антропология Евразии. - 2007. № 4 (32). - С. 143-157.

5. Лебедева, Е. Ю. Итоги археоботанических исследований на Среднем и Нижнем Дону в 20012003 гг. / Е. Ю. Лебедева // Археология Среднего Дона в скифскую эпоху: тр. Донской (б. Потуданской) археол.экспедиции ИА РАН. - М. : ИА РАН, 2004. - С. 119-127.

6. Обломский, А. М. Грунтовые погребения скифского времени у с. Ксизово на Верхнем Дону / А.М. Обломский, Ю.Д. Разуваев // Краткие сообщения Института археологии. - 2013. - Вып. 231. С. $183-194$.

7. Разуваев, Ю. Д. Могильник на Семилукском городище скифского времени в свете новых исследований / Ю. Д. Разуваев // Вестник ВГУ. Серия: История. Политология. Социология. - 2015. № 2. - С. 98-107.

8. Разуваев, Ю. Д. К этнокультурной характеристике населения донской лесостепи скифского времени (комплексные исследования бескурганных погребений) / Ю. Д. Разуваев, И. К. Решетова, М. В. Добровольская // Человек в окружающей среде: этапы взаимодействия : тез. 5-й Междунар. конф. «Алексеевские чтения». - М. : ИА РАН, 2013. - С. 81.

9. Савченко, Е. И. Могильник скифского времени «Терновое I - Колбино I» на Среднем Дону (погребальный обряд) / Е. И. Савченко // Археология Среднего Дона в скифскую эпоху : труды Потуданской археологической экспедиции ИА РАН. М. : ИА РАН, 2001. - С. 53-144.

10. Святко, С. В. Первые изотопные данные о диете населения тасмолинской культуры / С. В. Святко, А. 3. Бейсенов // Самарский научный вестник. 2017. - T. 6, № 3. - С. 223-227.
11. Чагаров, О. С. Изотопы азота и углерода в реконструкции питания и образа жизни среднедонского населения скифского времени (по материалам курганного могильника Терновое-Колбино) / О. С. Чагаров, М. В. Добровольская // Краткие сообщения Институга археологии. -2018. -Вып. 253.-С. 390- 402.

12. Чагаров, О. С. Система питания среднедонского населения скифского времени: хозяйство и природно-климатический фактор (по данным о составе стабильных изотопов углерода и азота) / О. С. Чагаров, М. В. Добровольская // Вестник Московского университета. Серия 23, Антропология. -2019 . - № 2. - С. 72-83.

13. Чикишева, Т. А. Динамика антропологической дифференциации населения Западной Сибири в эпохи неолита - раннего железного века / Т. А. Чикишева. - Новосибирск : Изд-во ин-та археологии и этнографии СО РАН, 2012. - 468 с.

14. Средневековое население Северо-Восточного Причерноморья (по материалам раскопок христианского храма у с. Веселое IX-XI вв.) / Т. Ю. Шведчикова [и др.] // Вестник антропологии. - 2016. Вып. 2(34).- С. 94-115.

15. Ancestry and Demography and Descendants of Iron Age Nomads of the Eurasian Steppe / M. Unterländer [et al.] // Nat Commun. 2017. - № 8. - Art. № 14615. - DOI: https://doi.org/ 10.1038/ncomms14615.

16. Bentley, A. R. Strontium Isotopes from the Earth to the Archaeological Skeleton / A. R. Bentley// AReview. J Archaeol Method Theory. - 2006. - Vol. 13. - P. 135187. -DOI: https://doi.org/10.1007/s10816-006-9009-x.

17. Bogaard, A. Crop Manuring and Intensive Land Management by Europe's First Farmers / A. Bogaard, R. Fraser, T. Heaton // Frontiers in Plant Science. - 2013.Vol. 110, № 31. - DOI: https://doi.org/10.1073/pnas. 1305918110 .

18. Gerling, C. Prehistoric Mobility and Diet in the West European Steppes 3500 to 300 BC. An Isotopic Approach Topoi / C. Gerling // Berlin Studies of the Ancient World. Vol. 25. - Berlin : Boston : Walter an Gruyter GmbH, 2015. - 402 p.

19. Paleodietary and Subsistence Strategy Investigation of the Iron Age TuobaXianbei Site by Stable Isotopic Analysis. A Preliminary Study of the Role of Agriculture Played in Pastoral Nomad Societies in Northern China / G. Znag [et al.] // Journal of Archaeological Science: Reports. - 2015. - Vol. 2. P. 699-707.

20. Palaeodietary Investigation of Carbon (13/ 12C) and Nitrogen (15/14) Stable Isotopes in Human Bone Collagen from Early Iron Age Burials at Aimyrlyg, Tuva / M.V. Dobrovolskaya [et al.] // Abstracts of $18^{\text {th }}$ Annual Meeting of European Association of Archaeologists (Helsinki, 29 ${ }^{\text {th }}$ of August- ${ }^{\text {st }}$ of September 2012). - Helsinki : [s. n.], 2012. - P. 162. 
21. Szpak', P. Complexities of Nitrogen Isotope Biogeochemistry in Plant-Soil Systems: Implications for the Study of Ancient Agricultural and Animal Management Practices / P. Szpak'// Frontiers in Plant Science. - 2014 - № 5 - - 288 p. - DOI: https://doi.org/ 10.3389/fpls.2014.00288.

22. Thianshanbeilu and the Isotopic Millet Road: reviuwing of late Neolithic / Bronze Age Radiation of Human Millet Consumption from North China to Europe /W. Tingting [et al.] // National Science Review. - 2019.Vol. 6, iss. 5. - P. 1024-1039. -DOI: https://doi.org/10.1093/ nsr/nwx015.

23. Wang, T. Investigating Dietary Patterns with Stable Isotope Ratios of Collagen and Starch Grain Analysis of Dental Calculus at the Iron Age Cemetery Site of Heigouliang, Xinjiang, China / T. Wang [et al.] // International Journal of Osteoarchaeology. Vol. 26, № 4. - P. 693-704.

\section{REFERENCES}

1. Gey A.N. Kurgan bronzovogo veka v mogilnike Ternovoe I [Bronze Age Kurgan in the Ternovoe I Burial Ground]. Arkheologiya Srednego Dona v skifskuyu epokhu: trudy Potudanskoy arkheologicheskoy ekspeditsii IA RAN [Middle Don Archaeology of the Scythian Time: Proceedings of the Potudan Archaeological Expedition of the Institute of Archaeology of the Russian Academy of Sciences]. Moscow, IA RAN, 2001, pp. 7-18.

2. Gulyaev V.I., Shevchenko A.A., Novye kurgannye mogilniki skifskogo vremeni na Srednem Donu: Gorki I i Devitsa V [New Burial Mounds of Scythian Time on the Middle Don: Gorki I and Devitsa V]. Moscow, IA RAN, 2017. 156 p.

3. Dobrovolskaya M.V., Reshetova I.K. Izotopnoe issledovanie antropologicheskikh materialov iz pogrebalnykh pamyatnikov epokhi bronzy na Srednem Donu [Isotope Study of Anthropological Materials from Funeral Monuments of the Bronze Age in the Middle Don]. Kratkie soobshcheniya instituta arkheologii [Brief Communications of the Institute of Archaeology], 2016, no. 245-II, pp. 172-181.

4. Kozintsev A.G. Skify Severnogo Prichernomorya: mezhgruppovye razlichiya, vneshnie svyazi, proiskhozhdenie [Scythians of the Northern Black Sea Region: Intergroup Differences, External Relations, Origin]. Arkheologiya, etnografiya $i$ antropologiya Evrazii [Archeology, Ethnography and Anthropology of Eurasia], 2007, no. 4 (32), pp. 143-157.

5. Lebedeva E. Yu. Itogi arkheobotanicheskikh issledovaniy na Srednem i Nizhnem Donu v 20012003 gg. [The Results of Archaeobotanical Research in the Middle and Lower Don in 2001-2003.]. Arkheologiya Srednego Dona v skifskuyu epokhu: tr. Donskoy (b. Potudanskoy) arkheol. ekspeditsii IA $R A N$ [Archaeology of the Middle Don in the Scythian Era: Works of the Don (Formerly Potudan) Archaeological Expedition of the Institute of Archaeology of the Russian Academy of Sciences]. Moscow, IA RAN, 2004, pp. 119-127.

6. Oblomskiy A.M., Razuvaev Yu.D. Gruntovye pogrebeniya skifskogo vremeni u s. Ksizovo na Verkhnem Donu [Ground Burials of the Scythian Time near the Village Ksizovo on the Upper Don]. Kratkie soobshcheniya Instituta arkheologii [Brief Communications of the Institute of Archaeology], 2013, iss. 231, pp. 183-194.

7. Razuvaev Yu.D. Mogilnik na Semilukskom gorodishche skifskogo vremeni $\mathrm{v}$ svete novykh issledovaniy [Burial Ground at the Semiluksky Settlement of Scythian Time in the Light of New Studies]. Vestnik VGU. Seriya: Istoriya. Politologiya. Sotsiologiya [Bulletin of the Voronezh State University. Series, History. Political Science. Sociology], 2015, no. 2, pp. 98-107.

8. Razuvaev Yu.D., Reshetova I.K., Dobrovolskaya M.V. K etnokulturnoy kharakteristike naseleniya donskoy lesostepi skifskogo vremeni (kompleksnye issledovaniya beskurgannykh pogrebeny) [On the Ethno-Cultural Characteristics of the Population of the Don Forest-Steppe of the Scythian Time (Complex Studies of Burials Without Barrows)]. Chelovek v okruzhayushchey srede: etapy vzaimodeystviya: tez. 5-y Mezhdunar. konf. «Alekseevskie chteniya» [Man in the Environment: Stages of Interaction. Proceedings of the $5^{\text {th }}$ International Conference "Alekseev Readings"]. Moscow, IA RAN, 2013, p. 81.

9. Savchenko E.I. Mogilnik skifskogo vremeni «Ternovoe I - Kolbino I» na Srednem Donu (pogrebalnyy obryad) [Burial Ground of Scythian Time "Ternovoe I - Kolbino I" on the Middle Don (Funeral Rite)]. Arkheologiya Srednego Dona v skifskuyu epokhu: trudy Potudanskoy arkheologicheskoy ekspeditsii IA RAN [Middle don archaeology of the Scythian time: Proceedings of the Potudan archaeological expedition of the Institute of Archaeology of the Russian Academy of Sciences]. Moscow, IA RAN, 2001, pp. 53-144.

10. Svyatko S.V., Beysenov A.Z. Pervye izotopnye dannye o diete naseleniya tasmolinskoy kultury [The First Isotopic Data on the Diet of the Population of Tasmola Culture]. Samarskiy nauchnyy vestnik [Samara Scientific Bulletin], 2017, vol. 6, no. 3, pp. 223-227.

11. Chagarov O.S., Dobrovolskaya M.V. Izotopy azota i ugleroda v rekonstruktsii pitaniya i obraza zhizni srednedonskogo naseleniya skifskogo vremeni (po materialam kurgannogo mogilnika Ternovoe-Kolbino) [Isotopes of Nitrogen and Carbon in the 
Reconstruction of Nutrition and Lifestyle of the Middle Don Population of the Scythian Time (Based on the Materials of the Ternovoe-Kolbino Burial Ground)]. Kratkie soobshcheniya Instituta arkheologii [Brief Communications of the Institute of Archaeology], 2018, iss. 253, pp. 390-402.

12. Chagarov O.S., Dobrovolskaya M.V. Sistema pitaniya srednedonskogo naseleniya skifskogo vremeni: khozyaystvo i prirodno-klimaticheskiy faktor (po dannym o sostave stabilnykh izotopov ugleroda $\mathrm{i}$ azota) [The Nutrition System of the Middle Don Population of the Scythian Time: Economy and the Climatic Factor (According to Data on the Composition of Stable Carbon and Nitrogen Isotopes)]. Vestnik Moskovskogo universiteta. Seriya 23, Antropologiya [Moscow University Journal, Series 23, Anthropology], 2019, no. 2, pp. 72-83.

13. Chikisheva T.A. Dinamika antropologicheskoy differentsiatsii naseleniya Zapadnoy Sibiri v epokhi neolita - rannego zheleznogo veka [The Dynamics of Anthropological Differentiation of the Population of Western Siberia in the Neolithic - Early Iron Age]. Novosibirsk, Izd-vo in-ta arkheologii i etnografii SO RAN, 2012. 468 p.

14. Shvedchikova T.Yu., Harlamova N.V., Rasskazova A.V., Chagarov O.S. Srednevekovoe naselenie Severo-Vostochnogo Prichernomorya (po materialam raskopok khristianskogo khrama u s. Veseloe IX-XI vv.) [The Medieval Population of the North-Eastern Black Sea Region (Based on Excavations of a Christian Church near the Village of Vesyoloye in the $9^{\text {th }}-11^{\text {th }}$ Centuries)]. Vestnik antropologii [Bulletin of Anthropology], 2016, iss. 2 (34), pp. 94-115.

15. Unterländer M., Palstra F., Lazaridis, Pilipenko A., Hofmanova Z, Melanie Gro M., Sel C., Jens Blochern J., Kirsanow K., Rohland N., Rieger B., Kaiser E., Schier W., Pozdniakov D., Khokhlov A., Georges M., Wilde S., Powel A., Heyer E., Currat M., Reich D., Samashev Z., He Parzinger H., Molodin V., Burger J. Ancestry and Demography and Descendants of Iron Age Nomads of the Eurasian Steppe. Nat Commun, 2017, no. 8, art. no. 14615. DOI: https://doi.org/10.1038/ncomms14615.

16. Bentley A.R. Strontium Isotopes from the Earth to the Archaeological Skeleton. A Review. J Archaeol Method Theory, 2006, vol. 13, pp. 135-187. DOI: https://doi.org/10.1007/s10816-006-9009-x.
17. Bogaard A., Fraser R., Heaton T. Crop Manuring and Intensive Land Management by Europes First Farmers. Frontiers in Plant Science, 2013, vol. 110, no. 31. DOI: https://doi.org/10.1073/ pnas. 1305918110.

18. Gerling C. Prehistoric Mobility and Diet in the West European Steppes 3500 to 300 BC. An Isotopic Approach Topoi. Berlin Studies of the Ancient World. Vol. 25. Berlin, Boston, Walter an Gruyter GmbH, 2015. 402 p.

19. Znag G., Hu Y., Cao C., Li X., Wu X., Sun Z., Chen F., Bai J., LV P., Song G., Wang C., Richards M. A Paleodietary and Subsistence Strategy Investigation of the Iron Age TuobaXianbei Site by Stable Isotopic Analysis. A Preliminary Study of the Role of Agriculture Played in Pastoral Nomad Societies in Northern China. Journal of Archaeological Science: Reports, 2015, vol. 2, pp. 699-707.

20. Dobrovolskaya M.V., Buzhilova A.P., Mednikova M.B., Tiunov A.V., Selezneva V.I., Moiseev V.G., Khartanovich V.I. Palaeodietary Investigation of Carbon (13/12C) and Nitrogen (15/14) Stable Isotopes in Human Bone Collagen from Early Iron Age Burials at Aimyrlyg, Tuva. Abstracts of $18^{\text {th }}$ Annual Meeting of European Association of Archaeologists (Helsinki, $29^{\text {th }}$ of August - $1^{\text {st }}$ of September 2012). Helsinki, [s. n.], 2012, p. 162.

21. Szpak' P. Complexities of Nitrogen Isotope Biogeochemistry in Plant-Soil Systems: Implications for the Study of Ancient Agricultural and Animal Management Practices. Frontiers in Plant Science, 2014, no. 5. 288 p. DOI: https://doi.org/10.3389/fpls. 2014.00288 .

22. Tingting W., Dong W., Chang X., Yu Zh., Zhang X., Wang Ch., Hu Y., Fuller B. Thianshanbeilu and the Isotopic Millet Road: reviuwing of late Neolithic / Bronze Age Radiation of Human Millet Consumption from North China to Europe. National Science Review, 2019, vol. 6, iss. 5, pp. 1024-1039. DOI: https://doi.org/10.1093/nsr/nwx015.

23. Wang T., Fuller B., Wei D., Chang X., Hu Y. Investigating Dietary Patterns with Stable Isotope Ratios of Collagen and Starch Grain Analysis of Dental Calculus at the Iron Age Cemetery Site of Heigouliang, Xinjiang, China. International Journal of Osteoarchaeology, 2016, vol. 26, no. 4, pp. 693-704. 


\section{Information About the Authors}

Maria V. Dobrovolskaya, Doctor of Sciences (History), Head of the Laboratory of Contextual Anthropology, Institute of Archaeology RAS, Dm. Ulyanova St, 19, 117292 Moscow, Russian Federation, mk_pa@mail.ru, https://orcid.org/0000-0001-9695-4199

Semen A. Volodin, Junior Researcher, Science Archive, Institute of Archaeology RAS, Dm. Ulyanova St, 19, 117292 Moscow, Russian Federation, volodinsaimon@gmail.com, https://orcid.org/0000-0003-3681-3241

\section{Информация об авторах}

Мария Всеволодовна Добровольская, доктор исторических наук, заведующая Лабораторией контекстуальной антропологии, Институт археологии РАН, ул. Дм. Ульянова, 19, 117292 г. Москва, Российская Федерация, mk_pa@mail.ru, https://orcid.org/0000-0001-9695-4199

Семен Алексеевич Володин, младший научный сотрудник Научно-отраслевого архива, Институт археологии РАН, ул. Дм. Ульянова, 19, 117292 г. Москва, Российская Федерация, volodinsaimon@gmail.com, https://orcid.org/0000-0003-3681-3241 